\title{
Is a Lead Isotope Ratios in Wine Good Marker for Origin Assessment?
}

\author{
Slađana Đurđić ${ }^{1}$, Vesna Stanković ${ }^{2}$, Slavica Ražić ${ }^{3 \star}$ and Jelena Mutić ${ }^{1}$ \\ ${ }^{1}$ Department of Analytical Chemistry, Faculty of Chemistry, University of Belgrade, Belgrade, Serbia, ${ }^{2}$ Department of Chemistry, \\ Institute of Chemistry, Technology and Metallurgy, University of Belgrade, Belgrade, Serbia, ${ }^{3}$ Department of Analytical Chemistry, \\ Faculty of Pharmacy, University of Belgrade, Belgrade, Serbia
}

Lead isotope ratio pattern $\left({ }^{206} \mathrm{~Pb} /{ }^{207} \mathrm{~Pb},{ }^{208} \mathrm{~Pb} /{ }^{206} \mathrm{~Pb},{ }^{206} \mathrm{~Pb} /{ }^{204} \mathrm{~Pb},{ }^{207} \mathrm{~Pb} /{ }^{204} \mathrm{~Pb}\right.$, and ${ }^{208} \mathrm{~Pb} /{ }^{204} \mathrm{~Pb}$ ) was analyzed in 59 samples of Serbian wine, from four geographical regions. By utilization of powerful inductively coupled plasma mass spectrometry (ICP-QMS), lead isotope ratios were used as unique "fingerprint", when combined with multivariate methods of analysis (Principal Component Analysis), provided information on the geographical origin of wine. In validation of ICP- QMS method and quantitative analysis, the certified reference material NIST SRM 981 was employed to test the mass-bias correction and thallium isotopes ${ }^{203} \mathrm{TI}$ and ${ }^{205} \mathrm{TI}$ (NIST SRM 997) as an

OPEN ACCESS

Edited by:

Eugenia Gallardo,

Universidade da Beira Interior,

Portugal

Reviewed by:

Tea Zuliani,

Institut Jožef Stefan (IJS), Slovenia

Yanbei Zhu,

National Institute of Advanced Industrial Science and Technology

(AIST), Japan

*Correspondence: Slavica Ražić

slavica.razic@pharmacy.bg.ac.rs

Specialty section:

This article was submitted to

Analytical Chemistry,

a section of the journal

Frontiers in Chemistry

Received: 24 July 2021 Accepted: 21 September 2021

Published: 04 October 2021

Citation:

Đurđić S, Stanković V, Ražić S and Mutić J (2021) Is a Lead Isotope Ratios in Wine Good Marker for Origin

Assessment?

Front. Chem. 9:746695

doi: 10.3389/fchem.2021.746695 internal standard. The obtained results were discussed in correlation with the corresponding values of LIRs of different European and Australian wines. In addition, the impact of anthropogenic $\mathrm{Pb}$ from different sources on the total $\mathrm{Pb}$ isotopic composition in Serbian wines was analyzed too. On the other side, the obtained values of $\mathrm{Pb}$ content were compared with the applicable health safety standards, according to the International Code of Oenological Practices.

Keywords: ICP-QMS, Serbian wines, principal component analysis, geographical origin, lead isotopes

\section{INTRODUCTION}

Lead isotopic composition, based on different ratios of stable isotopes $\left({ }^{206} \mathrm{~Pb} /{ }^{207} \mathrm{~Pb},{ }^{208} \mathrm{~Pb} /{ }^{206} \mathrm{~Pb}\right.$, ${ }^{206} \mathrm{~Pb} /{ }^{204} \mathrm{~Pb},{ }^{207} \mathrm{~Pb} /{ }^{204} \mathrm{~Pb}$, and ${ }^{208} \mathrm{~Pb} /{ }^{204} \mathrm{~Pb}$ ), serves as a "fingerprint" for definition of different lead sources in the environment (Erel et al., 1997; Larcher et al., 2003; Komárek et al., 2008; Đurđić et al., 2020). Analysis of the lead isotope ratios (LIRs) in food and beverages has provided a powerful tool for determining the geographical origin and authenticity, most often, of wine (Medina et al., 2000; Tian et al., 2000; Barbaste et al., 2001; Mihaljevič et al., 2006; Bora et al., 2018; Epova et al., 2020). In addition, LIRs can be used as a tool for elucidation of chemical environment in a mushrooms-soil system (Đurđić et al., 2020).

Primary, the presence of lead in wines originate from nature, where the vine reflected the isotopic signatures from the geological-pedological environment (natural lead; uncontaminated soli/ bedrock). On the other side, lead in wines can also be found as a result of human activities. Anthropogenic lead in wines mainly originates from traffic, fertilizer, pesticide treatment, as well as from metallurgical and smelting activities (Almeida and Vasconcelos, 1999; Đurđić et al., 2020). LIRs might provide information on the origin of the wine assuming that sources of contamination do not distort the original isotope ratio pattern present in the local environment (Tian et al., 2000). ${ }^{206} \mathrm{~Pb} /$ ${ }^{207} \mathrm{~Pb}$ and ${ }^{206} \mathrm{~Pb} /{ }^{208} \mathrm{~Pb}$ ratios could be significantly influenced by anthropogenic factors and may be used to differentiate natural and anthropogenic $\mathrm{Pb}$ contamination. On the other side, the chemical processes during winemaking have no significant influence on isotopic composition of wine 


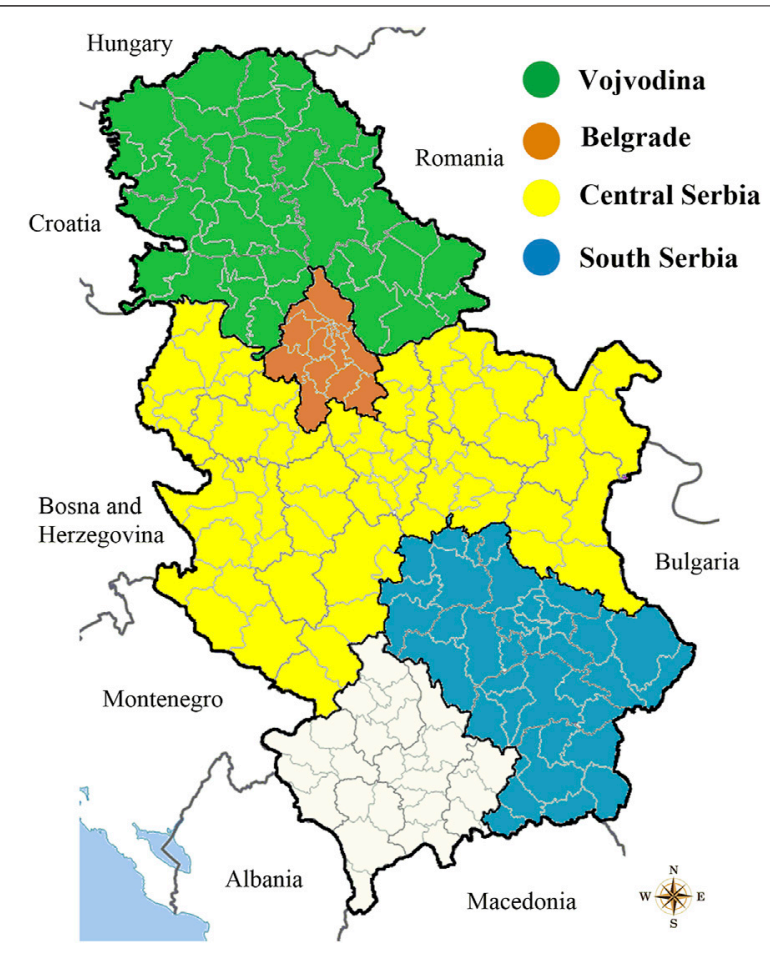

FIGURE 1 | Geographical regions of Serbia for provision of wine samples.

(Rosman et al., 1998). It was reported that the values of the isotope ratios between wines produced in a winery and laboratory were equivalent (Medina et al., 2000). However, the equipment used during the vinification can contribute substantially to the total lead content of the wine and $\mathrm{Pb}$ isotope ratios can deviate from those in the soil in the vineyard, which makes authentication rather difficult (Almeida and Vasconcelos, 2004). A precise and accurate lead isotope ratio measurements have been traditionally carried out by thermal ionization mass spectrometry (TIMS). The precision obtainable for isotope ratios determined by inductively coupled plasma mass spectrometry (ICP-QMS) is inherently worse than for many other types of mass spectrometers (Barbaste et al., 2001). For lead isotope ratio (LIR) measurements, the addition of thallium and the measurement of the ${ }^{203} \mathrm{Tl} /{ }^{205} \mathrm{Tl}$ ratio is good way to assess mass bias (Tian et al., 2000). ICP-QMS does not achieve the precision of TIMS but is considered as sufficient to differentiate the origin of wine (Almeida and Vasconcelos, 1999; Larcher et al., 2003; Mihaljevič et al., 2006). Fingerprinting techniques based on chemical composition and multivariate statistical analysis can be used to distinguish the wine origin one from another and to classify them according to region, quality, and type (Kment et al., 2005; Lara et al., 2005; Paneque et al., 2010; Martin et al., 2012).

There are no available data about the LIRs in Serbian wines so, the aim of this paper was to conduct such study (LIRs), to contribute to the databases of LIRs for European wines and to investigate possibility of using it in the discrimination of wine from different regions in Serbia using ICP-QMS.

\section{MATERIALS AND METHODS}

\section{Site Description}

A sample collection of 59 red wines originates from four different regions of Serbia: Vojvodina, Belgrade, Central Serbia and South Serbia. Distribution of wine samples is shown on the map (Figure 1). All wines were supplied in glass bottles with cork stopper.

\section{Reagents and Chemicals}

The certified reference material NIST SRM 981 (Common lead Isotopic standard, National Institute of Standards and Technology, United States) was employed to test the mass-bias correction and for standard solutions. As an internal standard used thallium isotopes ${ }^{203} \mathrm{Tl}$ and ${ }^{205} \mathrm{Tl}$ NIST SRM 997 (Isotope standard for Thallium, National Institute of Standards and Technology, United States). Mercury stock solution of 1,000 \pm $4 \mu \mathrm{g} / \mathrm{ml}$ (TraceCERT, Fluka, Dorset, United Kingdom) was used to study the isobaric interference, originating from ${ }^{204} \mathrm{Hg}$, on ${ }^{204} \mathrm{~Pb}$ measurements. All glassware was soaked in $10 \% \mathrm{HNO}_{3}$ for minimum $12 \mathrm{~h}$ and rinsed well with ultra-pure water. Ultrapure water was prepared by passing doubly de-ionized water from Milli-Q system (Millipore Simplicity 185 System incorporating dual UV filters (185 and $254 \mathrm{~nm})$ to remove carbon contamination). All chemicals were of analytical grade and were supplied by Merck (Darmstadt, Germany).

\section{Instrumentations}

Analytical measurements of $\mathrm{Pb}$ content and LIRs in wine samples were performed using an inductively coupled plasma mass spectrometer (ICP-MS iCAP Q, Thermo Scientific Xseries 2, United Kingdom) equipped with flat pole collision reaction cell, a micro-concentric nebulizer, nickel cones and a peristaltic sample delivery pump, running a quantitative analysis mode. The entire system controlled with Qtegra Instrument Control Software. The use of cooled spray chamber was found to be mandatory in order to minimize the effect of the ethanol matrix. Measured isotopes and instrument operating conditions for determination at ICP-QMS are given in Supplementary Table S1.

\section{Optimization of Instrumental Parameters for LIRs Analysis}

TIMS and ICP sector field multicollector mass spectrometry provides high precision and accuracy during isotope ratios analysis. On the other hand, isotope ratios measurements by ICP-QMS are considered as insufficiently accurate and precise (Vanhaecke et al., 2009), because of the "sequential" measuring approach. Therefore, it is necessary to optimize certain instrumental parameters in order to improve these crucial analytical parameters during the determination of LIRs by ICP-QMS.

The major goal in the isotope ratio measurements by ICP is to achieve constancy of the instrumental mass-bias with the time. Mass-bias effect (mass discrimination) is a feature of all ICPQMS instruments and occurs due to differential ions transfer from the sample introduction system to the signal detection. 
TABLE 1 | Validation of proposed method. Comparison of certified values of NIST SRM 981 with obtained LIRs by ICP-QMS using different correction protocols on massbias effect (Đurđić et al., 2020).

\begin{tabular}{|c|c|c|c|}
\hline LIRs & Certified value \pm SD & $\begin{array}{c}\text { Found value } \pm \text { SD }^{\mathbf{a}} \\
\text { (the correction was } \\
\text { performed with external } \\
\text { standardization using NIST } \\
\text { SRM 981) }\end{array}$ & $\begin{array}{c}\text { Found value } \pm S^{a} \\
\text { (the correction was } \\
\text { performed with internal } \\
\text { standardization using NIST } \\
\text { SRM 997) }\end{array}$ \\
\hline${ }^{207} \mathrm{~Pb} /{ }^{206} \mathrm{~Pb}$ & $0.91464 \pm 0.00033$ & $0.9146 \pm 0.0008$ & $0.9191 \pm 0.0007$ \\
\hline${ }^{208} \mathrm{~Pb} /{ }^{206} \mathrm{~Pb}$ & $2.1681 \pm 0.0008$ & $2.1679 \pm 0.0009$ & $2.1449 \pm 0.0008$ \\
\hline${ }^{204} \mathrm{~Pb} /{ }^{206} \mathrm{~Pb}$ & $0.059042 \pm 0.000037$ & $0.058 \pm 0.003$ & $0.057 \pm 0.002$ \\
\hline
\end{tabular}

${ }^{a} S D-$ standard deviation $(n=6)$.

Accordingly, ICP-QMS has not the same sensitivity for different masses, due to differences in ion transmission and detection (Devulder et al., 2013). This phenomenon causes a difference between the true values and the obtained LIRs data (Đurđić et al., 2020; Marguí et al., 2007). Therefore, it is mandatory to correct the instrumental LIRs data on the mass-bias effect in order to improve accuracy in LIRs measurements. External and internal standardization can be used for data correction. External correction is based on the use of NIST SRM 981, while NIST SRM 997 was applied for internal standardization (Marguí et al., 2007; Vanhaecke et al., 2009). Also, for the correction of instrumental LIRs data, it is necessary to calculate the bias factor $(K)$. For calculation of $K$, a linear, potential or exponential algorithm can be used (Đurđić et al., 2020; Marguí et al., 2007). In Table 1, the values of LIRs of the certified reference material NIST SRM 981 were compared with LIRs instrumental data after their correction to the massbias effect, using external and internal standardization with potential algorithm (Đurđić et al., 2020). As noted, external standardization ensured the best compliance of the obtained LIRs of NIST SRM 981 with the certified values of the standard material. Accordingly, this approach was applied to correct all obtained LIRs in wine samples. Finally, the correction of instrumental LIRs data for each wine sample was performed using "bracketing" sequences where the sample was analyzed between two runs of standard solution (Vanhaecke et al., 2009). "Bracketing" was done with standard solution of $5.12 \mu \mathrm{g} / \mathrm{L}$ of lead. In addition, the matrix effect significantly contributes to the mass-bias effect. Matrix effect is dependent on the absolute concentration of matrix components and the most satisfactory methods to eliminate the matrix effect is to remove matrix elements. For that purpose, a large number of chromatographic techniques using chelating or ion exchange column can be used (Jones and Nesterenko, 1997). We tried overcoming matrix effects using the dilution approach due to sample dilution is an easy and effective method to reduce the severity of matrix effects. Several dilutions of the wine sample were tested in order to study the evolution of signal suppression. A dilution factor of 25 demonstrated to be enough to eliminate most of the matrix effects.

In addition to correction of LIRs for mass-bias effect, dwell time for each isotope and dead time of detector were optimized in order to increase precision and accuracy of measurements, respectively. These instrumental parameters were optimized by
NIST SRM 981 reference material. Standard solution of $5.12 \mu \mathrm{g} / \mathrm{L}$ of lead, spiked with $2 \mu \mathrm{g} / \mathrm{L}$ of thallium, was measured in six points per peak and five replicants, applying different dwell times. Dwell time for each isotope was optimized based on lowest relative standard deviation (RSD) between replicants (Encinar et al., 2001; Marguí et al., 2007). For majority of the analyzed isotopes, RSDs ranged from 0.10 to $0.15 \%$, while RSD for ${ }^{204} \mathrm{~Pb}$ was $0.32 \%$. Finally, the optimized dwell time was $100 \mathrm{~ms}$ for ${ }^{204} \mathrm{~Pb}, 5 \mathrm{~ms}$ for ${ }^{208} \mathrm{~Pb}$, while the dwell times for isotopes ${ }^{206} \mathrm{~Pb},{ }^{207} \mathrm{~Pb},{ }^{208} \mathrm{~Pb},{ }^{203} \mathrm{Tl}$ and ${ }^{205} \mathrm{Tl}$ were set to $25 \mathrm{~ms}$. In the case of dead time optimization, Nelms et al. (2001) presents several methods for optimizing this parameter. In this paper, ${ }^{204} \mathrm{~Pb} /{ }^{208} \mathrm{~Pb}$ was monitored as a function of different lead concentrations (10-30 $\mu \mathrm{g} / \mathrm{L})$, applying different dead times (25, 30, 35, 40 and $45 \mathrm{~ns})$. Dead time of $40 \mathrm{~ns}$ was selected as optimal, after linear fitting of the regression line, where the slope of the regression line was close to zero (Nelms et al., 2001; Đurđić et al., 2020). Also, when discussing about the detector of ICP-QMS device, the mode in which the detector operates during LIRs measurements is essential. In this study, all LIRs were analyzed in pulse detector mode. The working range of lead concentration, which provides the operation of the detector of our ICP-QMS device in pulse mode, is up to $40 \mu \mathrm{g} / \mathrm{L}$. Therefore, a dilution factor of 25 (Sample preparation) was sufficient to keep the lead concentration below the critical value, but at the same time, as stated, a dilution of 25 times was sufficient to minimize the matrix effect.

In the end, since ${ }^{204} \mathrm{~Pb}$ is subject to isobaric interference of ${ }^{204} \mathrm{Hg}$, a correction of ${ }^{204} \mathrm{~Pb}$ intensity for ${ }^{204} \mathrm{Hg}$ was performed (Marguí et al., 2007; Đurđić et al., 2020).

\section{Sample Preparation}

For determination of $\mathrm{Pb}$ content, all wine samples were diluted with ultra-pure water (1:10) and directly analyzed. All samples were contained $\mathrm{HNO}_{3}$ in final concentration of $2 \%(\mathrm{v} / \mathrm{v})$. Blank was prepared as standard solutions and wine samples with ultrapure water and contained $\mathrm{HNO}_{3}$ in concentration of $2 \%(\mathrm{v} / \mathrm{v})$. Further presented $\mathrm{Pb}$ concentrations refer to values after blank correction.

For LIRs analysis in wine, samples were diluted with ultrapure water. Depending of $\mathrm{Pb}$ concentration, dilution factor was 10 or 25. This dilution protocol was done in order to provide the pulse mode of the detector, which is mandatory in LIRs analysis. Thallium, as internal standard, was added to all samples in final concentration of $2 \mu \mathrm{g} / \mathrm{L}$. All wine samples were contained $\mathrm{HNO}_{3}$ 
TABLE 2 | Pb isotopic composition and $\mathrm{Pb}$ content in red wines from four Serbian regions.

\begin{tabular}{|c|c|c|c|c|c|c|c|}
\hline \multirow[t]{2}{*}{ Regions of Serbia } & \multirow[t]{2}{*}{ Statistical parameters } & \multicolumn{5}{|c|}{ Lead isotope ratios } & \multirow[t]{2}{*}{$\mathrm{Pb}(\mu \mathrm{g} / \mathrm{L})$} \\
\hline & & ${ }^{206} \mathrm{~Pb} /{ }^{204} \mathrm{~Pb}$ & ${ }^{208} \mathrm{~Pb} /{ }^{206} \mathrm{~Pb}$ & ${ }^{207} \mathrm{~Pb} /{ }^{204} \mathrm{~Pb}$ & ${ }^{208} \mathrm{~Pb} /{ }^{204} \mathrm{~Pb}$ & ${ }^{206} \mathrm{~Pb} /{ }^{207} \mathrm{~Pb}$ & \\
\hline \multirow[t]{3}{*}{ Vojvodina } & average $\pm S D^{a}$ & $18.3 \pm 0.2$ & $2.13 \pm 0.03$ & $16.0 \pm 0.2$ & $38.9 \pm 0.5$ & $1.145 \pm 0.002$ & $65.0 \pm 32.6$ \\
\hline & Min & 17.9 & 2.10 & 15.7 & 38.1 & 1.111 & 14.9 \\
\hline & Max & 18.5 & 2.16 & 16.3 & 39.6 & 1.168 & 117.6 \\
\hline \multirow[t]{3}{*}{ Belgrade } & average $\pm S D$ & $18.3 \pm 0.4$ & $2.14 \pm 0.03$ & $16.0 \pm 0.2$ & $38.7 \pm 0.7$ & $1.141 \pm 0.003$ & $44.4 \pm 29.6$ \\
\hline & Min & 17.6 & 2.10 & 15.6 & 37.4 & 1.112 & 12.6 \\
\hline & Max & 18.6 & 2.17 & 16.2 & 39.8 & 1.170 & 100.3 \\
\hline \multirow[t]{3}{*}{ Central Serbia } & average $\pm S D$ & $18.3 \pm 0.4$ & $2.14 \pm 0.03$ & $16.0 \pm 0.3$ & $39.0 \pm 0.7$ & $1.145 \pm 0.002$ & $48.8 \pm 35.1$ \\
\hline & Min & 17.5 & 2.10 & 15.6 & 37.6 & 1.112 & 11.5 \\
\hline & Max & 18.6 & 2.17 & 16.3 & 39.9 & 1.171 & 114.5 \\
\hline \multirow[t]{3}{*}{ South Serbia } & average $\pm S D$ & $18.3 \pm 0.3$ & $2.14 \pm 0.02$ & $16.0 \pm 0.3$ & $39.1 \pm 0.5$ & $1.145 \pm 0.003$ & $58.0 \pm 44.8$ \\
\hline & Min & 17.9 & 2.10 & 15.6 & 38.0 & 1.116 & 14.5 \\
\hline & Max & 18.6 & 2.17 & 16.2 & 39.9 & 1.171 & 126.1 \\
\hline
\end{tabular}

${ }^{a} S D-$ standard deviation between samples.

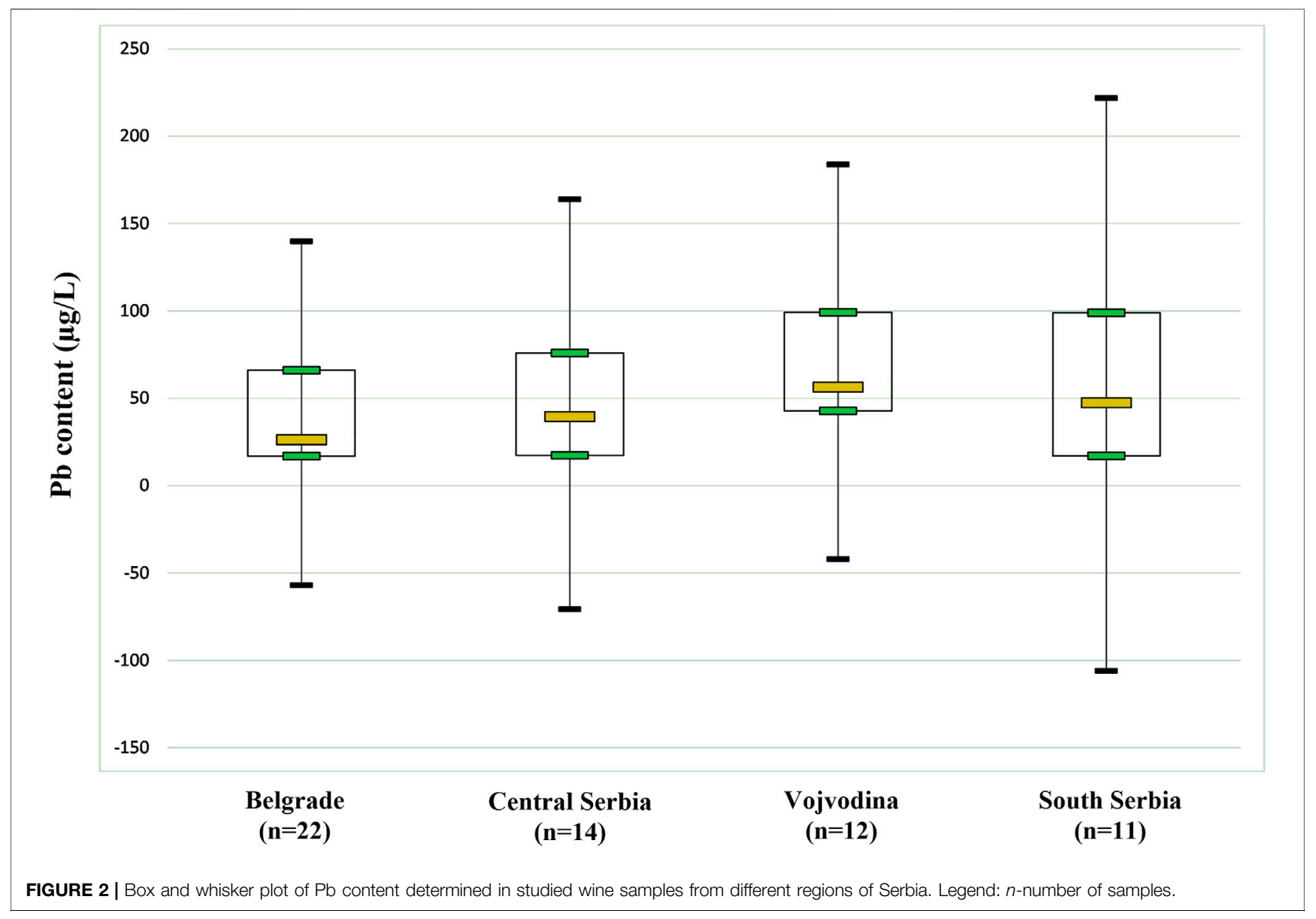

in concentration of $2 \%(\mathrm{v} / \mathrm{v})$. Blank was prepared as standard solutions and wine samples, with ultra-pure water, thallium solution and $\mathrm{HNO}_{3}$. Final concentration of thallium and $\mathrm{HNO}_{3}$ in blank were $2 \mu \mathrm{g} / \mathrm{L}$ and $2 \%(\mathrm{v} / \mathrm{v})$, respectively. Blank correction has been done for each wine sample.

\section{Statistical Analysis}

Descriptive statistics, correlation analysis and Mann-Whitney $U$ test were performed by NCSS software package, www.ncss.com (Hintze, 2001). All data produced were statistically treated to find possible statistically significant differences between the variables 


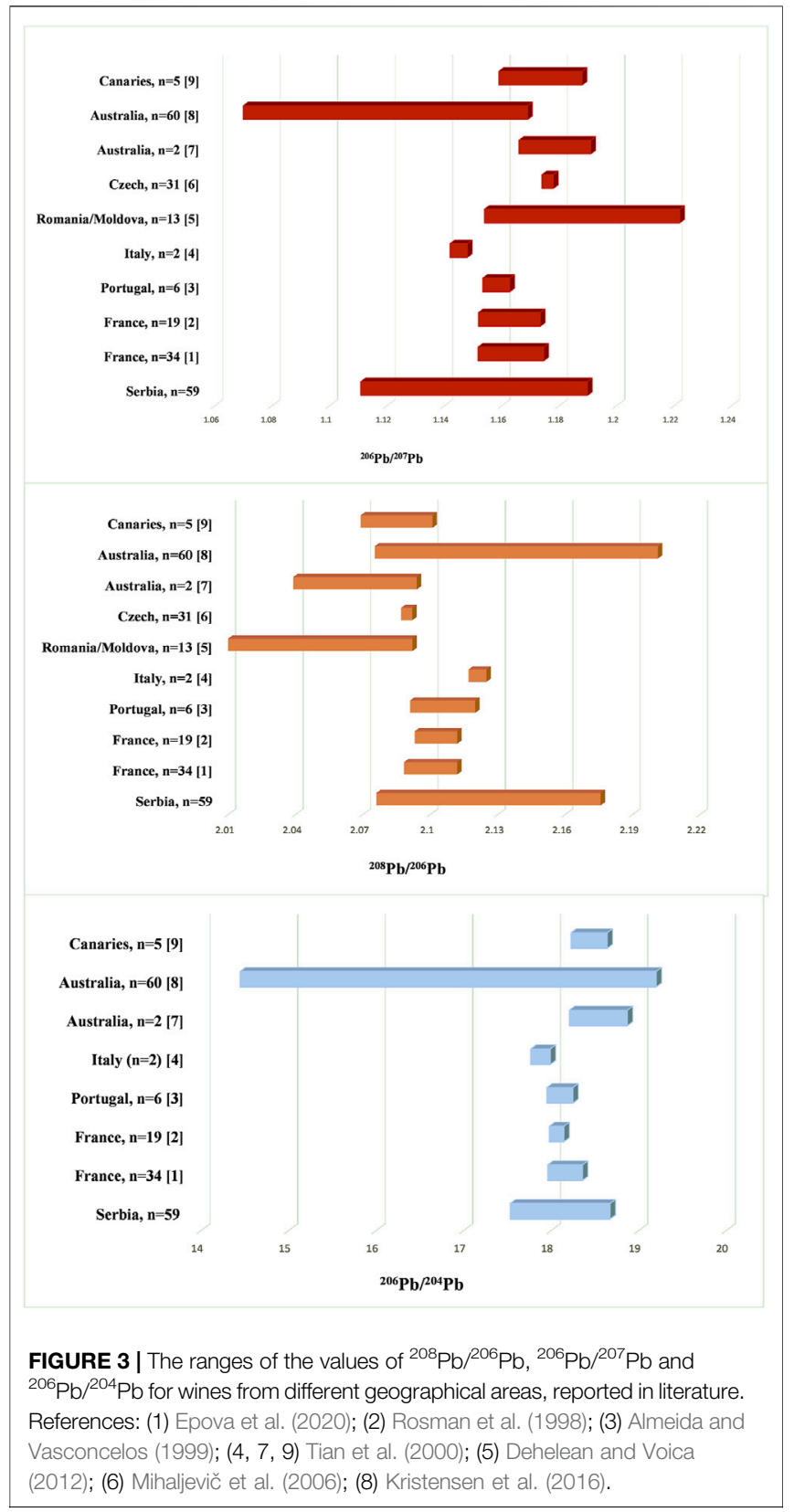

with the aid of the nonparametric tests: Kruskal-Wallis and Mann-Whitney U. Principal component analysis (PCA) was carried out by PLS ToolBox, v.6.2.1, for MATLAB 7.12.0 (R2011a).

\section{RESULTS AND DISCUSSION}

\section{Determination of Lead Content in Wine Samples}

Basic statistical parameters of $\mathrm{Pb}$ analysis, for both of its total content and the isotopic ratios, are summarized in Table 2. The highest average content of $\mathrm{Pb}$ was recorded in samples from Vojvodina, while further $\mathrm{Pb}$ content decreases in the following order: South Serbia $>$ Central Serbia $>$ Belgrade. In general, the lowest $\mathrm{Pb}$ content was $11.50 \pm 0.05 \mu \mathrm{g} / \mathrm{L}$ (Central Serbia), while the highest was $126.10 \pm 0.09 \mu \mathrm{g} / \mathrm{L}$ (South Serbia). Although a relatively high $\mathrm{Pb}$ content was found, it is important to point out that all tested wines are in accordance with the applicable health safety standards: The International Code of Oenological Practices (OIV code, 2019) defines a maximum $\mathrm{Pb}$ content in food and beverages of $150 \mu \mathrm{g} / \mathrm{L}$ (this value refers to wines produced since 2007).

Figure 2 represents the distribution of lead content in red wine samples from different Serbian regions. Vojvodina, Belgrade, Central Serbia and South Serbia, characterized by medians of 56.4, 26.3, 39.6, and 47.4, respectively. This non-parametric test demonstrates if there are significant differences between the regions.

\section{Lead Isotope Profile in Serbian Wines}

According to our best knowledge, this is the first time that LIRs analysis in Serbian wines has been done. The average LIRs (average \pm SD) by their geographical origin are presented in Table 2. Small differences among the wines from the Serbian regions were observed for the ${ }^{208} \mathrm{~Pb} /{ }^{206} \mathrm{~Pb},{ }^{206} \mathrm{~Pb} /{ }^{207} \mathrm{~Pb}$, and ${ }^{208} \mathrm{~Pb} /{ }^{204} \mathrm{~Pb}$ ratios. On another hand, average values of ${ }^{207} \mathrm{~Pb} /$ ${ }^{204} \mathrm{~Pb}$ and ${ }^{206} \mathrm{~Pb} /{ }^{204} \mathrm{~Pb}$ were very similar in all Serbian regions. Minimal changes occur due to the fact that isotope ${ }^{207} \mathrm{~Pb}$ changes slowly in time, in comparison with ${ }^{208} \mathrm{~Pb}$ and ${ }^{206} \mathrm{~Pb}$ isotopes, since ${ }^{235} \mathrm{U}$ generally decayed, while the abundance of ${ }^{232} \mathrm{Th}$ and ${ }^{238} \mathrm{U}$ is still relatively high on Earth (Komárek et al., 2008).

The obtained results showed that Serbian wines covered central part of the ${ }^{208} \mathrm{~Pb} /{ }^{206} \mathrm{~Pb},{ }^{206} \mathrm{~Pb} /{ }^{207} \mathrm{~Pb}$ and ${ }^{206} \mathrm{~Pb} /{ }^{204} \mathrm{~Pb}$ ratios and are in concordance with LIRs of different European wines (Figure 3). In this case, ranges of ${ }^{208} \mathrm{~Pb} /{ }^{206} \mathrm{~Pb},{ }^{206} \mathrm{~Pb} /{ }^{207} \mathrm{~Pb}$, and ${ }^{206} \mathrm{~Pb} /{ }^{204} \mathrm{~Pb}$ ratios were from 2.0760 to $2.1758,1.1109$ to 1.1898 and 17.53 to 18.67 , respectively. Ranges of ${ }^{208} \mathrm{~Pb} /{ }^{206} \mathrm{~Pb}$ and ${ }^{206} \mathrm{~Pb} /{ }^{204} \mathrm{~Pb}$ ratios of Serbian wines were also within the wide ranges of Australian red wines $\left({ }^{208} \mathrm{~Pb} /{ }^{206} \mathrm{~Pb}\right.$ - from 2.0753 to $2.2013 ;{ }^{206} \mathrm{~Pb} /{ }^{204} \mathrm{~Pb}$-from 14.45 to 19.20 ) reported by Kristensen et al. (2016), while values of ${ }^{206} \mathrm{~Pb} /{ }^{207} \mathrm{~Pb}$ of our wines were slightly higher than reported $\left({ }^{206} \mathrm{~Pb} /{ }^{207} \mathrm{~Pb}\right.$-from 1.0700 to 1.1690$)$. On the other hand, Australian and Canaries wines reported by Tian et al. (2000) slightly coincide with the observed LIRs of Serbian wines. The different $\mathrm{Pb}$ isotopic composition of the mentioned wines in relation to Serbian wines potentially indicates a different source of $\mathrm{Pb}$ pollution in the observed regions (Komárek et al., 2008). On the other hand, Romanian/Moldavian wines were characterized by very low ${ }^{208} \mathrm{~Pb} /{ }^{206} \mathrm{~Pb}$ range (1.9961-2.0920) and a significantly high range of ${ }^{206} \mathrm{~Pb} /{ }^{207} \mathrm{~Pb}(1.1540-1.2220)$ compared to Serbian wines. Such $\mathrm{Pb}$ isotopic composition in Romanian/Moldavian wines is suspected to coal combustion whose isotope ratios values are similar to natural lead (Komárek et al., 2008; Dehelean and Voica, 2012).

\section{Tracing the Geographical Origin of Wines by Non-Radiogenic ${ }^{204} \mathrm{~Pb}$ Isotope}

In order to define the geographical origin of wine, it is necessary to consider the geogenic ${ }^{204} \mathrm{~Pb}$. According to a priori knowledge 

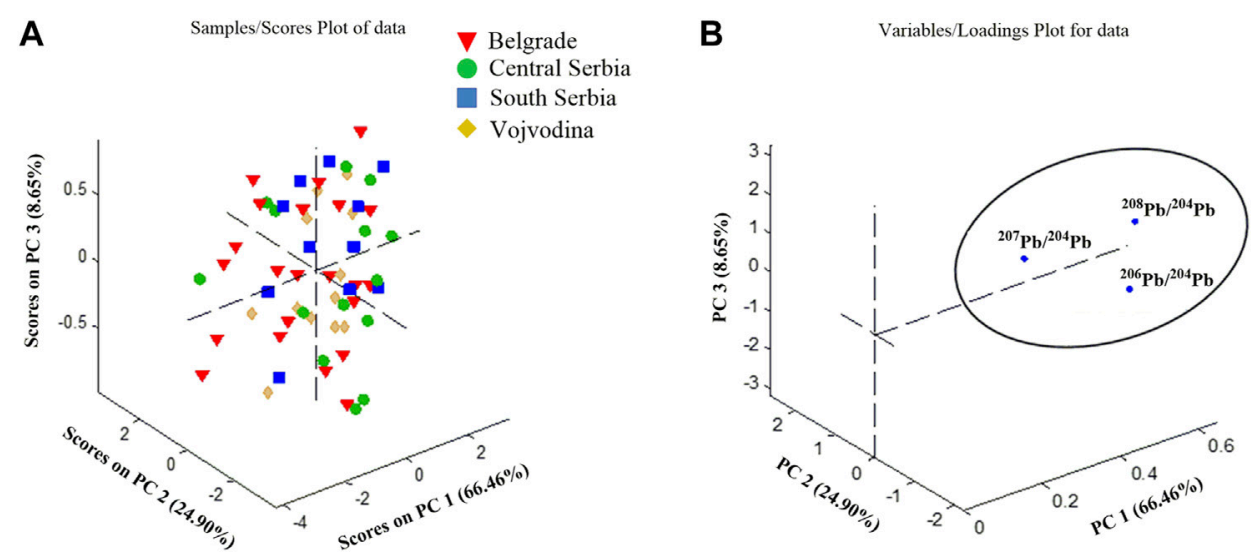

FIGURE 4 | PCA model for distribution of LIRs in Serbian wines; (A) a score plot; (B) loading plot.
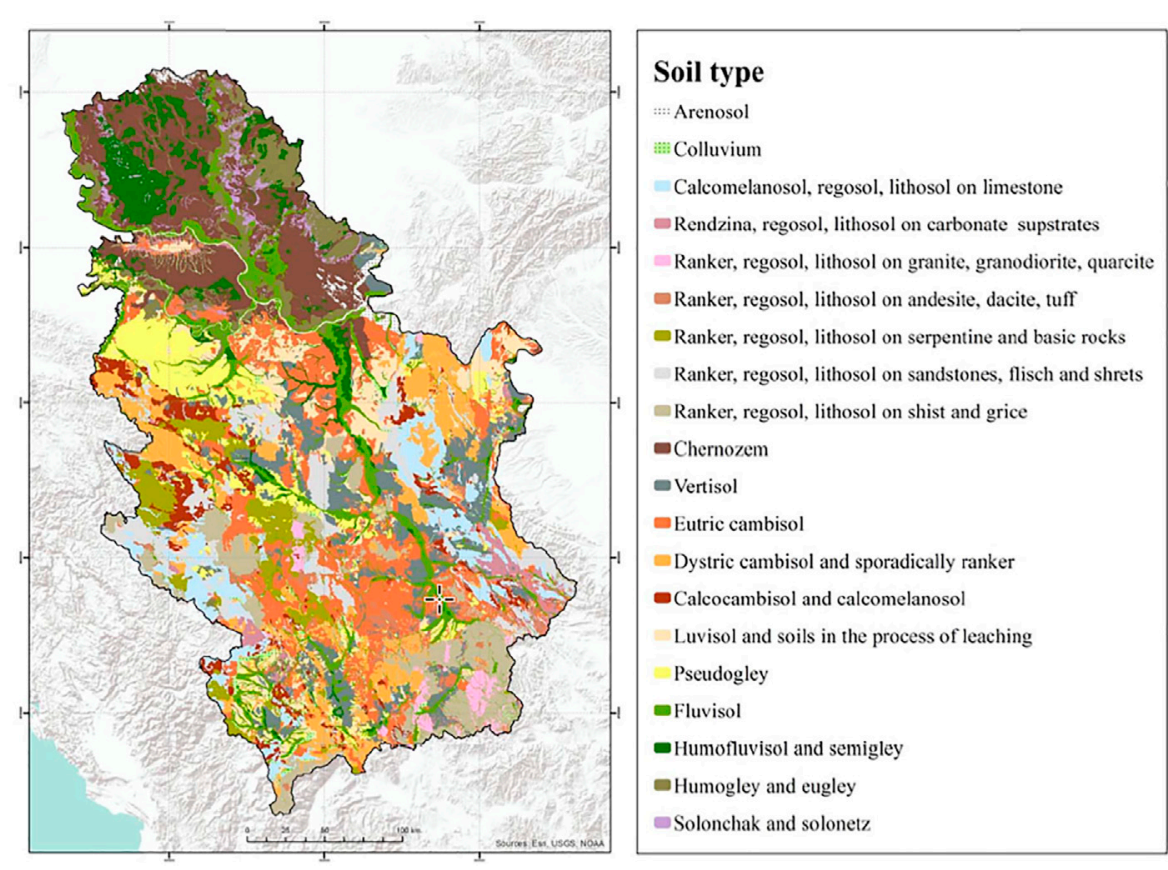

FIGURE 5 | The map of Republic of Serbia according to the type of soil (Čakmak et al., 2018).

and environmental research, the ${ }^{204} \mathrm{~Pb}$ isotope defines natural $\mathrm{Pb}$ sources in environmental samples (Epova et al., 2020). In that sense, the content of ${ }^{204} \mathrm{~Pb}$ in wines shows the isotopic composition in wine, and the corresponding soil, where the grape was grown, since the plant inherits isotopic signatures from the geological-pedological environment. In this way, the authenticity of the wine can be established (Martins et al., 2014; Bora et al., 2018; Epova et al., 2020).

For this purpose, the content of ${ }^{204} \mathrm{~Pb}$ was discussed and correlated with the radiogenic isotopes ${ }^{208} \mathrm{~Pb},{ }^{207} \mathrm{~Pb}$ and ${ }^{206} \mathrm{~Pb}$. The corresponding LIRs of all four Serbian regions $\left({ }^{208} \mathrm{~Pb} /{ }^{204} \mathrm{~Pb}\right.$, ${ }^{207} \mathrm{~Pb} /{ }^{204} \mathrm{~Pb}$, and ${ }^{206} \mathrm{~Pb} /{ }^{204} \mathrm{~Pb}$ ) were subjected to the Principal Component Analysis (PCA). All data were autoscaled prior to any multivariate analysis to bring values to compatible units. PCA was carried out as an exploratory data analysis by using a singular value decomposition algorithm and a 0.95 confidence level for $\mathrm{Q}$ and T2 Hotelling limits for outliers. The analysis was based on correlation matrix and factors with eigenvalues greater than one were retained. Sample scores and their loadings for the three PCs (PC1, PC2, and PC3), responsible for $100 \%$ of total variance, are presented in Figure 4. With a score plot (Figure 4A), the complete overlap of all regions of Serbia was obtained, while the loading graph (Figure 4B) clearly indicates the grouping according to all analyzed LIRs. It means that no relevant discrimination of wines according to their geographical origin was observed. 


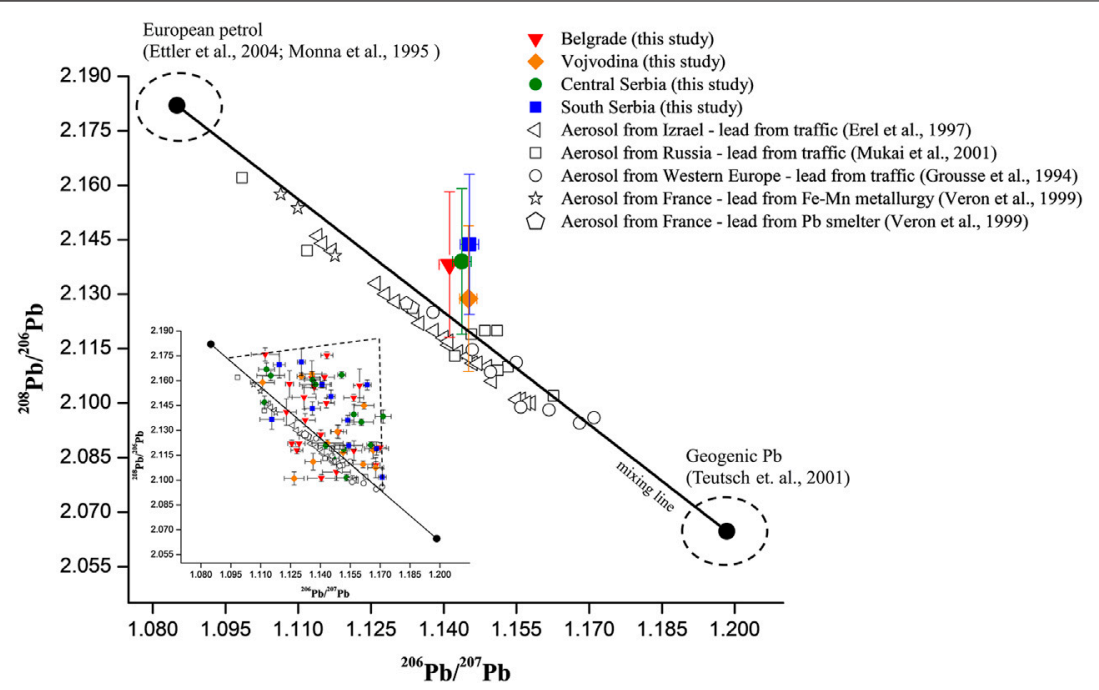

FIGURE 6 | Plot of average ${ }^{208} \mathrm{~Pb} /{ }^{206} \mathrm{~Pb}$ and average ${ }^{206} \mathrm{~Pb} /{ }^{207} \mathrm{~Pb}$ of analyzed Serbian wines. Error bars represent standard deviations between samples. Comparison with identical LIRs in aerosols from different European countries. Inset figure represent distribution of ${ }^{208} \mathrm{~Pb} /{ }^{206} \mathrm{~Pb}$ and ${ }^{206} \mathrm{~Pb} /{ }^{207} \mathrm{~Pb}$ for individual wine samples from four Serbian regions.
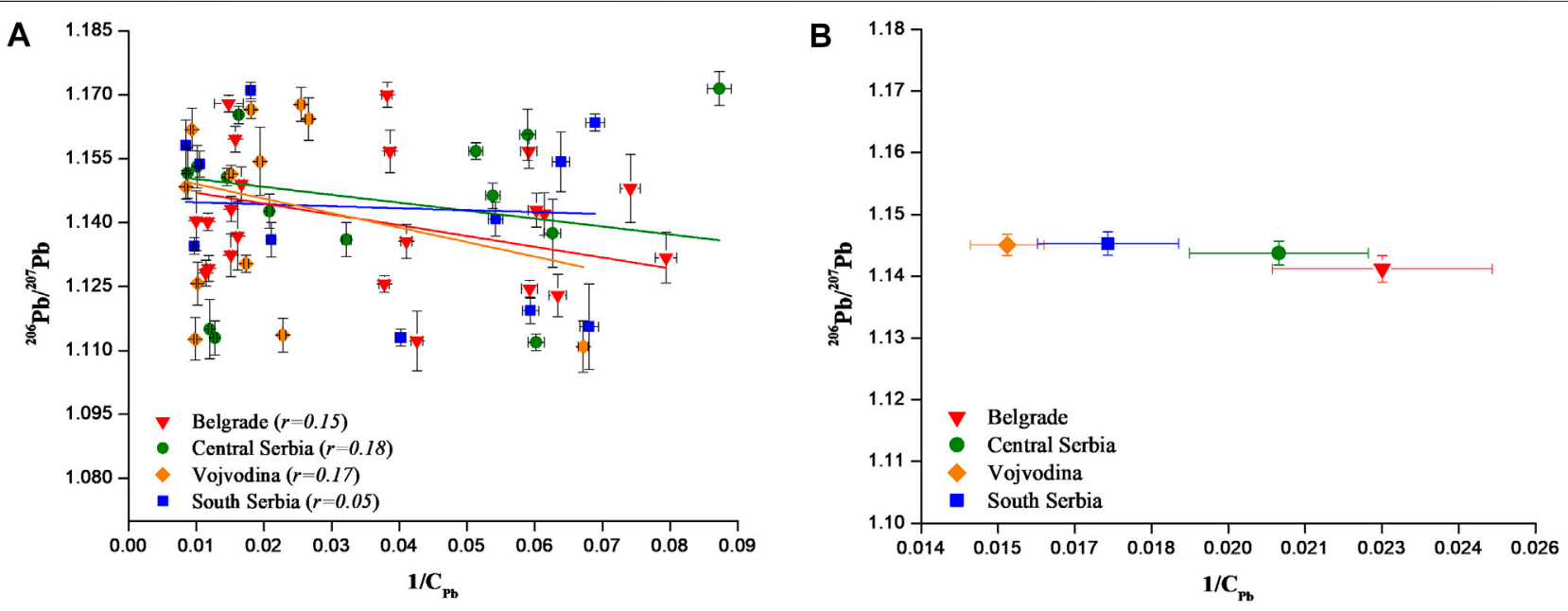

FIGURE 7 | (A) Possible isotopic signature of pollutant Pb sources in Serbian wines determined from ${ }^{206} \mathrm{~Pb} /{ }^{207} \mathrm{~Pb}$ ratio vs. 1/C $\mathrm{Pb}$. (B) $\mathrm{Plot}$ of average ${ }^{206} \mathrm{~Pb} /{ }^{207} \mathrm{~Pb}$ ratio vs. average $1 / \mathrm{C}_{\mathrm{Pb}}$ for four Serbian regions. Error bars represent standard deviations between samples.

The map of the Republic of Serbia (Čakmak et al., 2018) shows different soil profile in regions (Figure 5). It is clear that Vojvodina, as the largest Serbian plain, is characterized by chernozem and humofluvisol. In the area of Belgrade, eutric cambisol and luvisol soil types are dominant. Central and South Serbia, as a hilly and mountainous segment of Serbia, is characterized by diverse soil type such as vertisol, eutric cambisol, calcomelanosol and ranker. Among other factors, different soil types reflect different content of macro and micro elements (including $\mathrm{Pb}$ ), as result of different processes in pedogenesis (Čakmak et al., 2018; Vukojević et al., 2019). Since the content of ${ }^{204} \mathrm{~Pb}$ in wines (in combination with other LIRs) reflects the isotopic composition in the corresponding soil, the recognition of Serbian regions is foreseen. However, anthropogenic sources can influence the $\mathrm{Pb}$ isotopic composition and should not be neglected.

\section{Tracing Anthropogenic Influences Using ${ }^{208} \mathrm{~Pb} /{ }^{206} \mathrm{~Pb}$ and ${ }^{206} \mathrm{~Pb} /{ }^{207} \mathrm{~Pb}$}

In environmental studies, plotting of ${ }^{208} \mathrm{~Pb} /{ }^{206} \mathrm{~Pb}$ vs. ${ }^{206} \mathrm{~Pb} /{ }^{207} \mathrm{~Pb}$ is used to identify different sources of $\mathrm{Pb}$ contamination such as natural, geogenic $\mathrm{Pb}$ (rock and soil formation) and anthropogenic (emissions from cars, industrial existence, metal activities, smelters ... ) (Erel et al., 1997; Larcher et al., 2003; Komárek et al., 2008; Đurđić et al., 2020). 
Lead particles emitted into the atmosphere are mostly retained in the atmosphere (atmospheric $\mathrm{Pb}$ ), exhibiting $\mathrm{Pb}$ isotopic signature of atmospheric aerosol (Flament et al., 2002). It was reported that the average size of the anthropogenic $\mathrm{Pb}$ particle was about $0.9 \mu \mathrm{m}$, although the size of the emitted $\mathrm{Pb}$ particles varies depending on the source of pollution. The problem with contaminated aerosol occurs due to uncontrolled aerosol transport as a consequence of various climatic factors. This leads to difficulties to define $\mathrm{Pb}$ isotopic profile, as well as to identify sources of $\mathrm{Pb}$ pollution (Komárek et al., 2008). According to the reported data, the dust particles, originating from the Sahara, contribute significantly to the $\mathrm{Pb}$ isotopic composition in the European aerosol (Doucet and Carignan, 2001; Grousset et al., 1994). Erel et al. (2002), analyzing LIRs in atmospheric aerosol in Jerusalem (Israel), found a significant contribution of $\mathrm{Pb}$ that does not originate from a local source, but from other parts of the World (Eastern Europe, Turkey and Egypt). For example, LIRs in French wine from 19 different vintage (1950-1991), were influenced by contribution of $\mathrm{Pb}$ variations in aerosol (Rosman et al., 1998). Kristensen et al. (2016) defined the LIRs in Australian wines in correlation to leaded gasoline, especially during the 1960s and 1970s. The authors explained that influence of $\mathrm{Pb}$ in the atmospheric aerosol significantly contributed to the total $\mathrm{Pb}$ isotopic composition in wine. Besides, clearly separation from the LIRs obtained for the vineyard soil was observed (Kristensen et al., 2016). In this study, we compared average values of LIRs of Serbian wines from different regions with literature data (Erel et al., 1997; Grousset et al., 1994; Kristensen et al., 2016; Mukai et al., 2001; Véron et al., 1999) related to atmospheric aerosol containing $\mathrm{Pb}$ from different anthropogenic sources (leaded gasoline from different regions/countries, Fe-Mn metallurgy, $\mathrm{Pb}$ smelter) and presented on Figure 6. Three-isotopes "mixing line" $\left({ }^{208} \mathrm{~Pb} /{ }^{206} \mathrm{~Pb}\right.$ vs. $\left.{ }^{206} \mathrm{~Pb} /{ }^{207} \mathrm{~Pb}\right)$, obtained between the geogenic (Teutsch et al., 2001) and the anthropogenic LIRs, characterizes European petrol (as the most common anthropogenic source of $\mathrm{Pb}$ ) (Ettler et al., 2004; Monna et al., 1995). The graph shows a very good accordance of the "mixing line" with LIRs characterized by $\mathrm{Pb}$ from traffic, Fe-Mn metallurgy and $\mathrm{Pb}$ smelter. LIRs of Serbian wines were distributed along the "mixing line" (inset Figure 6), what is in accordance with the literature data (Erel et al., 1997; Grousset et al., 1994; Kristensen et al., 2016; Mukai et al., 2001; Véron et al., 1999). From Figure 6, the average values of LIRs for four Serbian regions are proximately equivalent to one another and showed a typical value of the mixture of European petrol and geogenic $\mathrm{Pb}$. This indicates that $\mathrm{Pb}$ in the aerosol from different sources significantly contributed to the total $\mathrm{Pb}$ isotopic composition in Serbian wines. On the other hand, a scattering of LIRs data of Serbian wines from "mixing line", in the shape of an imaginary triangle, was observed (inset Figure 6). Such scattering was described by Vanhaecke et al. (2009), explaining that $\mathrm{Pb}$ isotopic composition in environmental samples is, in majority of cases, defined by more than two $\mathrm{Pb}$ sources. Unknown or uncategorized sources of pollution have to be considered as well.

The vinification process is also one of the important sources of lead contamination of wine. The vinification process begins with the grape harvest and continues with the transport of grapes to the winery, the crushing of grapes and the addition of pectolytic enzyme preparations for maceration and antioxidants (ascorbic acid and tannin). These processes were followed by the addition of wine yeast to the must, filtration of the must, as well as sulfurization with certain doses of $\mathrm{SO}_{2}$-based compounds to final products in bottles. All these vinification steps represent potential sources of lead in wine (Almeida and Vasconcelos, 2003; Stockley et al., 2003). Recently, with the massive introduction of stainless-steel devices the contamination level was drastically reduced, but still, during traditional vinification protocol, a long contact of wine with $\mathrm{Pb}$ equipment significantly contributes to $\mathrm{Pb}$ isotope composition in wine (Almeida and Vasconcelos, 2003). This influence is especially pronounced in the preparation of red wine, since the maceration process is one of the main processes in its production. We believe that $\mathrm{Pb}$ from the vinification process, in addition to leaded gasoline, metallurgical activities/smelters, also contributed to the total $\mathrm{Pb}$ isotopic composition in wines. On the other side, this synergistic effect of all those influences cause difficulties to define Serbian wine regions.

In a final step, the isotope ratio ${ }^{206} \mathrm{~Pb} /{ }^{207} \mathrm{~Pb}$ was correlated with $1 / \mathrm{C}_{\mathrm{Pb}}\left(\mathrm{C}_{\mathrm{Pb}}-\mathrm{Pb}\right.$ concentration $)$ and the obtained results graphically presented on Figure 7A. When statistically reliable, the extrapolation of $1 / \mathrm{C}_{\mathrm{Pb}}$ toward 0 provides the isotopic signature of the source of contamination, assuming it is a single source with a constant isotopic composition (Erel et al., 1997; Ndung'u et al., 2011). However, the Pearson correlation coefficient (r) for analyzed wines from four Serbian regions was from 0.05 to 0.18 . Such a correlation indicates that there is no statistically significant difference between ${ }^{206} \mathrm{~Pb} /{ }^{207} \mathrm{~Pb}$ and $1 / \mathrm{C}_{\mathrm{Pb}}$ due to the large variance of the data, indicating possible multiple sources of lead pollution (Ndung'u et al., 2011). This is also consistent with data discussed and presented on Figure 6. In addition, plot of average ${ }^{206} \mathrm{~Pb} /{ }^{207} \mathrm{~Pb}$ vs. average of $1 / \mathrm{C}_{\mathrm{Pb}}$ for all Serbian regions (Figure $7 \mathbf{B}$ ) showing that the LIRs are independent of $\mathrm{Pb}$ concentration.

\section{CONCLUSION}

In this work, systematic analysis of lead isotope profile in Serbian wines from four regions was conducted. The obtained results are discussed in order to identify potential sources of lead pollution and compared with those for European and Australian wines. The obtained values of the ${ }^{208} \mathrm{~Pb} /{ }^{206} \mathrm{~Pb},{ }^{206} \mathrm{~Pb} /{ }^{207} \mathrm{~Pb}$, and ${ }^{206} \mathrm{~Pb} /{ }^{204} \mathrm{~Pb}$ ratios of Serbian wines are comparable to ratios reported for other European areas and contribute to the databases for lead isotope profiles of European wines. Further evaluation showed that, in addition to natural $\mathrm{Pb}$, various anthropogenic sources such as leaded gasoline, $\mathrm{Fe}-\mathrm{Mn}$ metallurgy, $\mathrm{Pb}$ smelter contribute to the total $\mathrm{Pb}$ isotopic profile of Serbian wines. Besides, the vinification process is also suspected to have a significant influence.

LIRs are powerful tool for tracing the origin of wine on condition that a single source of influence i.e., pollution is previously confirmed. In the case of multiple sources of influence isotopic signatures are not significantly different due to large variance of data. In any case, both fully validated ICPQMS analysis and overall methodology, coupled with multivariate method of analysis (PCA) offer the best approach to answer the entitled question of tracing the origin of wine, determining the authenticity and geographical origin of wine. 


\section{DATA AVAILABILITY STATEMENT}

The original contributions presented in the study are included in the article/Supplementary Material, further inquiries can be directed to the corresponding author.

\section{AUTHOR CONTRIBUTIONS}

SĐ and VS performed all the work, analysed, interpreted data and drafted this manuscript. SR and JM planned, designed, critically revised this paper and supervised all the work.

\section{REFERENCES}

Almeida, C. M. R., and Vasconcelos, M. T. S. D. (1999). Determination of lead Isotope Ratios in Port Wine by Inductively Coupled Plasma Mass Spectrometry after Pre-treatment by UV-Irradiation. Analytica Chim. Acta 396, 45-53. doi:10.1016/s0003-2670(99)00356-6

Almeida, C. M. R., and Vasconcelos, M. T. S. D. (2004). Does the Winemaking Process Influence the Wine $87 \mathrm{Sr} / 86 \mathrm{Sr}$ ? A Case Study. Food Chem. 85, 7-12. doi:10.1016/j.foodchem.2003.05.003

Almeida, C. M. R., and Vasconcelos, M. T. S. D. (2003). Lead Contamination in Portuguese Red Wines from the Douro Region: from the Vineyard to the Final Product. J. Agric. Food Chem. 51, 3012-3023. doi:10.1021/jf0259664

Barbaste, M., Halicz, L., Galy, A., Medina, B., Emteborg, H., C. Adams, F., et al. (2001). Evaluation of the Accuracy of the Determination of lead Isotope Ratios in Wine by ICP MS Using Quadrupole, Multicollector Magnetic Sector and Time-Of-Flight Analyzers. Talanta 54, 307-317. doi:10.1016/s0039-9140(00) 00651-2

Bora, F. D., Donici, A., Rusu, T., Bunea, A., Popescu, D., and Bunea, C. I. (2018). Elemental Profile and $207 \mathrm{~Pb} / 206 \mathrm{~Pb}, 208 \mathrm{~Pb} / 206 \mathrm{~Pb}, 204 \mathrm{~Pb} / 206 \mathrm{~Pb}, 87 \mathrm{Sr} / 86 \mathrm{Sr}$ Isotope Ratio as Fingerprints for Geographical Traceability of Romanian Wines. Not. Bot. Horti Agrobo. 46 (1), 223-239. doi:10.15835/nbha46110853

Cakmak, D., Perovic, V., Kresovic, M., Jaramaz, D., Mrvic, V., Belanovic Simic, S., et al. (2018). Spatial Distribution of Soil Pollutants in Urban green Areas (A Case Study in Belgrade). J. Geochem. Explor. 188, 308-317. doi:10.1016/ j.gexplo.2018.02.001

Dehelean, A., and Voica, C. (2012). Determination of lead and Strontium Isotope Ratios in Wines by Inductively Coupled Plasma Mass Spectrometry. Rom. Journ. Phys. 57, 1194-1203.

Devulder, V., Lobo, L., Van Hoecke, K., Degryse, P., and Vanhaecke, F. (2013). Common Analyte Internal Standardization as a Tool for Correction for Mass Discrimination in Multi-Collector Inductively Coupled Plasma-Mass Spectrometry. Spectrochim. Acta B: At. Spectrosc. 89, 20-29. doi:10.1016/ j.sab.2013.08.009

Doucet, F. J., and Carignan, J. (2001). Atmospheric Pb Isotopic Composition and Trace Metal Concentration as Revealed by Epiphytic Lichens:. Atmos. Environ. 35, 3681-3690. doi:10.1016/s1352-2310(00)00510-0

Encinar, J. R., Alonso, J. I. G., Sanz-Medel, A., Main, S., and Turner, P. J. (2001). A Comparison between Quadrupole, Double Focusing and Multicollector ICP-MS Instruments : Part I. Evaluation of Total Combined Uncertainty for lead Isotope Ratio Measurements. J. Anal. Spectrom. 16, 315-321. doi:10.1039/b006145j

Epova, E. N., Bérail, S., Séby, F., Barre, J. P. G., Vacchina, V., Médina, B., et al. (2020). Potential of lead Elemental and Isotopic Signatures for Authenticity and Geographical Origin of Bordeaux Wines. Food Chem. 303, 125277. doi:10.1016/ j.foodchem.2019.125277

Erel, Y., Axelrod, T., Veron, A., Mahrer, Y., Katsafados, P., and Dayan, U. (2002). Transboundary Atmospheric lead Pollution. Environ. Sci. Technol. 36, 3230-3233. doi:10.1021/es020530q

Erel, Y., Veron, A., and Halicz, L. (1997). Tracing the Transport of Anthropogenic lead in the Atmosphere and in Soils Using Isotopic Ratios. Geochim. et Cosmochim. Acta 61, 4495-4505. doi:10.1016/s0016-7037(97)00353-0

\section{FUNDING}

This research was financially supported by the Ministry of Education, Science and Technological Development of Republic of Serbia (contract numbers: 451-03-9/2021-14/ 200168 and 451-03-68/2020-14/200161).

\section{SUPPLEMENTARY MATERIAL}

The Supplementary Material for this article can be found online at: https://www.frontiersin.org/articles/10.3389/fchem.2021.746695/ full\#supplementary-material

Ettler, V., Mihaljevic, M., and Komárek, M. (2004). ICP-MS Measurements of lead Isotopic Ratios in Soils Heavily Contaminated by lead Smelting: Tracing the Sources of Pollution. Anal. Bioanal. Chem. 378 (2), 311-317. doi:10.1007/ s00216-003-2229-y

Flament, P., Bertho, M.-L., Deboudt, K., Véron, A., and Puskaric, E. (2002). European Isotopic Signatures for lead in Atmospheric Aerosols: a Source Apportionment Based upon 206Pb/207Pb Ratios. Sci. Total Environ. 296, 35-57. doi:10.1016/s0048-9697(02)00021-9

Grousset, F. E., Quetel, C. R., Thomas, B., Buat-Menard, P., Donard, O. F. X., and Bucher, A. (1994). Transient Pb Isotopic Signatures in the Western European Atmosphere. Environ. Sci. Technol. 28, 1605-1608. doi:10.1021/es00058a011

Hintze, J. (2001). NCSS and PASS Number Crucher Statistical Systems. Kaysville. Available at: www.ncss.com.

Jones, P., and Nesterenko, P. N. (1997). High-Performance Chelation Ion Chromatography: A New Dimension in the Separation and Determination of Trace Metals. J. Chromatogr. A. 789, 413-435. doi:10.1016/S0021-9673(97) 00824-8

Kment, P., Mihaljevič, M., Ettler, V., Šebek, O., Strnad, L., and Rohlová, L. (2005). Differentiation of Czech Wines Using Multielement Composition - A Comparison with Vineyard Soil. Food Chem. 91, 157-165. doi:10.1016/ j.foodchem.2004.06.010

Komárek, M., Ettler, V., Chrastný, V., and Mihaljevič, M. (2008). Lead Isotopes in Environmental Sciences: a Review. Environ. Int. 34 (4), 562-577. doi:10.1016/ j.envint.2007.10.005

Kristensen, L. J., Taylor, M. P., and Evans, A. J. (2016). Tracing Changes in Atmospheric Sources of lead Contamination Using lead Isotopic Compositions in Australian Red Wine. Chemosphere 154, 40-47. doi:10.1016/ j.chemosphere.2016.03.023

Lara, R., Cerutti, S., Salonia, J. A., Olsina, R. A., and Martinez, L. D. (2005). Trace Element Determination of Argentine Wines Using ETAAS and USN-ICP-OES. Food Chem. Toxicol. 43, 293-297. doi:10.1016/j.fct.2004.10.004

Larcher, R., Nicolini, G., and Pangrazzi, P. (2003). Isotope Ratios of lead in Italian Wines by Inductively Coupled Plasma Mass Spectrometry. J. Agric. Food Chem. 51, 5956-5961. doi:10.1021/jf021064r

Marguí, E., Iglesias, M., Queralt, I., and Hidalgo, M. (2007). Precise and Accurate Determination of lead Isotope Ratios in Mining Wastes by ICP-QMS as a Tool to Identify Their Source. Talanta 73, 700-709. doi:10.1016/ j.talanta.2007.04.051

Martin, A. E., Watling, R. J., and Lee, G. S. (2012). The Multi-Element Determination and Regional Discrimination of Australian Wines. Food Chem. 133, 1081-1089. doi:10.1016/j.foodchem.2012.02.013

Martins, P., Madeira, M., Monteiro, F., Bruno de Sousa, R., Curvelo-Garcia, A. S., and Catarino, S. (2014). 87Sr/86Sr Ratio in Vineyard Soils from Portuguese Denominations of Origin and its Potential for Origin Authentication. OENO One 48 (1), 21-29. doi:10.20870/oeno-one.2014.48.1.1652

Medina, B., Augagneur, S., Barbaste, M., Grousset, F. E., and Buat-Menard, P. (2000). Influence of Atmospheric Pollution on the lead Content of Wines. Food Addit. Contam. 17, 435-445. doi:10.1080/02652030050034019

Mihaljevič, M., Ettler, V., Šebek, O., Strnad, L., and Chrastny, V. (2006). Lead Isotope Signatures of Wine and Vineyard Soils-Tracers of lead Origin. J. Geochem. Explor. 88, 130-133. doi:10.1016/j.gexplo.2005.08.025 
Monna, F., Benothman, D., and Luck, J. (1995). Pb Isotopes and Pb, Zn and Cd Concentrations in the Rivers Feeding a Coastal Pond (Thau, Southern France): Constraints on the Origin(s) and Flux(es) of Metals. Sci. Total Environ. 166 (13), 19-34. doi:10.1016/0048-9697(95)04514-2

Mukai, H., Machida, T., Tanaka, A., Vera, Y. P., and Uematsu, M. (2001). Lead Isotope Ratios in the Urban Air of Eastern and central Russia. Atmos. Environ. 35, 2783-2793. doi:10.1016/s1352-2310(00)00341-1

Ndung'u, K., Hibdon, S., Véron, A., and Flegal, A. R. (2011). Lead Isotopes Reveal Different Sources of lead in Balsamic and Other Vinegars. Sci. Total Environ. 409, 2754-2760. doi:10.1016/j.scitotenv.2011.04.001

Nelms, S. M., Quétel, C. R., Prohaska, T., Vogl, J., and Taylor, P. D. P. (2001). Evaluation of Detector Dead Time Calculation Models for ICP-MS. J. Anal. Spectrom. 16, 333-338. doi:10.1039/b007913h

OIV code (2019). International Code of Oenological Practices. Available at: http:// www.oiv.int/public/medias/6558/code-2019-en.pdf (Accessed December 19, 2020).

Paneque, P., Álvarez-Sotomayor, M. T., Clavijo, A., and Gómez, I. A. (2010). Metal Content in Southern Spain Wines and Their Classification According to Origin and Ageing. Microchem. J. 94, 175-179. doi:10.1016/ j.microc.2009.10.017

Rosman, K. J. R., Chisholm, W., Jimi, S., Candelone, J.-P., Boutron, C. F., Teissedre, P.-L., et al. (1998). Lead Concentrations and Isotopic Signatures in Vintages of French Wine between 1950 and 1991. Environ. Res. 78, 161-167. doi:10.1006/ enrs.1997.3812

Stockley, C. S., Smith, L. H., Tiller, t. 1. K. G., Gulson, B. L., Osborn, C. D. A., and Lee, T. H. (2003). Lead in Wine: a Case Study on Two Varieties at Two Wineries in South Australia. Aust. J. Grape Wine Res. 9, 47-55. doi:10.1111/j.17550238.2003.tb00231.x

Teutsch, N., Erel, Y., Halicz, L., and Banin, A. (2001). Distribution of Natural and Anthropogenic lead in Mediterranean Soils. Geochim. et Cosmochim. Acta 65 (17), 2853-2864. doi:10.1016/s0016-7037(01)00607-x

Tian, X., Emteborg, H. k., Barbaste, M., and Adams, F. C. (2000). Accuracy and Precision of lead Isotope Ratios in Wines Measured by Axial Inductively
Coupled Plasma Time of Flight Mass Spectrometry. J. Anal. Spectrom. 15, 829-835. doi:10.1039/b001026j

Vanhaecke, F., Balcaen, L., and Malinovsky, D. (2009). Use of Single-Collector and Multi-Collector ICP-Mass Spectrometry for Isotopic Analysis. J. Anal. Spectrom. 24, 863-886. doi:10.1039/b903887f

Véron, A., Flament, P., Bertho, M. L., Alleman, L., Flegal, R., and Hamelin, B. (1999). Isotopic Evidence of Pollutant lead Sources in Northwestern France. Atmos. Environ. 33, 3377-3388. doi:10.1016/s1352-2310(98)00376-8

Vukojević, V., Đurđić, S., Stefanović, V., Trifković, J., Čakmak, D., Perović, V., et al. (2019). Scandium, Yttrium, and Lanthanide Contents in Soil from Serbia and Their Accumulation in the Mushroom Macrolepiota Procera (Scop.) Singer. Environ. Sci. Poll. Res. 26, 5422-5434. doi:10.1007/s11356-018-3982-y

Đurđić, S., Stanković, V., Ražić, S., and Mutić, J. (2020). Lead Isotope Ratios as Tool for Elucidation of Chemical Environment in a System of Macrolepiota Procera (Scop.) Singer - Soil. Environ. Sci. Pollut. Res.. doi:10.1007/s11356-020-07947-6

Conflict of Interest: The authors declare that the research was conducted in the absence of any commercial or financial relationships that could be construed as a potential conflict of interest.

Publisher's Note: All claims expressed in this article are solely those of the authors and do not necessarily represent those of their affiliated organizations, or those of the publisher, the editors and the reviewers. Any product that may be evaluated in this article, or claim that may be made by its manufacturer, is not guaranteed or endorsed by the publisher.

Copyright (C) 2021 Đurdić, Stanković, Ražić and Mutić. This is an open-access article distributed under the terms of the Creative Commons Attribution License (CC BY). The use, distribution or reproduction in other forums is permitted, provided the original author(s) and the copyright owner(s) are credited and that the original publication in this journal is cited, in accordance with accepted academic practice. No use, distribution or reproduction is permitted which does not comply with these terms. 